\title{
RELATIONSHIP BETWEEN HEMATOLOGICAL PARAMETERS AND GLYCEMIC CONTROL IN TYPE 2 DIABETES MELLITUS PATIENTS
}

\author{
POVEZANOST HEMATOLOŠKIH PARAMETARA I GLIKOREGULACIJE \\ KOD PACIJENATA SA DIJABETES MELITUSOM TIP 2
}

\author{
Dragana Milosevic ${ }^{1,2}$, Violeta Lukic Panin ${ }^{2}$ \\ ${ }^{1}$ Department of Laboratory Diagnostics, Health Care Center "Dr Milorad Mika Pavlovic«, Indjija, Serbia \\ ${ }^{2}$ Faculty of Medicine, University of Novi Sad, Novi Sad, Serbia
}

\section{Summary}

Background: Diabetes mellitus (DM) with its micro- and macrocomplications is the leading global epidemic of the 21 st century. The aim of the research is to determine possible changes in the complete blood count (CBC) parameters depending on glycemic controlin patients with Type 2 diabetes mellitus (T2DM).

Methods: The study included a total of 178 patients with T2DM, both gender over the age of 40 years, from the Health Care Center "Dr Milorad Mika Pavlović" Indjija, Serbia. To notice the possible correlation between the CBC parameters and glucose control in T2DM, the subjects were divided in two groups with $\mathrm{HbA} 1 \mathrm{c} \leq 7 \%$ and with $\mathrm{HbA} 1 \mathrm{c}>7 \%$. We analysed $\mathrm{CBC}$ parameters, parameters of glycoregulation, lipid status using standard biochemical methods, performed anthropometric measurements and collected patients data by questionnaire and electronic patient card.

Results: There was statistical difference between $\mathrm{HbA} 1 \mathrm{c}$ groups for PMDW $(p=0.045), \operatorname{HDL}(p=0.0067)$. Using univariate linear regression it is shown that $\mathrm{PCT}$ was correlated with WBC $(p=0.0005)$, neutrophils $(p=0.046)$, monocytes $(p=0.003) ; M P M$ was associated with MPV $(p=0.0005) ;$ MPC $(p=0.0005)$, PDW $(P=0.0005)$, GLUO $(p=0.034), H D L-C(p=0.005) ; P M D W$ was correlated with HbA1c\% $(p=0.049)$, GLUO ( $p=0.013), \operatorname{HDL}-C(p=0.001)$, BW $(p=0.043)$ in all patients.

\begin{abstract}
Kratak sadržaj
Uvod: Diabetes mellitus (DM) sa mikro i makrokomplikacijama je vodeća globalna epidemija 21. veka. Cilj istraživanja je da se utvrde eventualne promene parametara kompletne krvne slike (KKS) u zavisnosti od glikoregulacije kod pacijenata sa šećernom bolesti tip 2 (DM tip 2).

Metode: Istraživanjem je obuhvaćeno ukupno 178 pacijenata sa DM tip 2, oba pola, starijih od 40 godina, iz Doma zdravlja »Dr Milorad Mika Pavlović«; Inđija, Srbija. Da bi se utvrdila moguća povezanost između parametara KKS i glikoregulacije u T2DM, ispitanici su podeljeni u dve grupe, sa $\mathrm{HbA} 1 \mathrm{c} \leq 7 \%$ i sa vrednostima $\mathrm{HbA} 1 \mathrm{c}>7 \%$. Analizirani su parametri KKS, parametri glikoregulacije, lipidni status korišćenjem standardnih biohemijskih postupaka, a vršena su i antropometrijska merenja. Podaci od pacijenata prikupljeni su putem upitnika i elektronskog kartona pacijenta.

Rezultati: Utvrđena je statistički značajna razlika između grupa za PMDW ( $p=0,045)$, HDL-C ( $p=0,0067)$. Kod svih pacijenata (univarijabilna linearna regresija) rezultati su pokazali daje PCT povezan sa leukocitima $(p=0,0005)$, neutrofilima $(p=0,046)$, monocitima $(p=0,003)$; MPM je u korelaciji sa MPV $(p=0,0005) ; M P C(p=0,0005), P D W$ $(p=0,0005)$, GLUO $(p=0,034)$, HDL-C $(p=0,005)$; PMDW je u korelaciji sa HbA1c\% $(p=0,049), \operatorname{GLUO}(p=0,013)$, HDL-C $(p=0,001)$, telesnom masom $(p=0,043)$.
\end{abstract}

Address for correspondence:

Dragana Milosevic, Department of Laboratory Diagnostics, Health Care Center "Dr Milorad Mika Pavlovic“,

Srpskocrkvena 5, Indjija 22320, Serbia

Tel: +38122510035

Fax: +38122510035

e-mail: draganam99@yahoo.com 
Conclusions: Based on our study results it may be concluded that some of the parameters of CBC could be useful tool in following glycemic control of diabetics.

Keywords: T2DM, CBC parameters, platelets, HbA1c

\section{Introduction}

Diabetes mellitus (DM) is the leading global epidemic of the 21st century with over 422 million diabetics worldwide. The prediction of prevalence of diabetes mellitus patients by 2035 according to the World Health Organization (WHO) is 592 million patients (1). In the Republic of Serbia, 710,000 people or $12.4 \%$ of the population suffer from DM, and the increase in the number of patients is estimated to be $15.2 \%$ by 2035 (2).

Blood is classified as a connective tissue, with cellular elements suspended in plasma. Elevated blood glucose level in T2DM contributes to disturbance ofblood cells and its indices (3). Good glycemic control is the main recommendation in the prevention of the development of diabetic complications. It has been suggested that early normalization of glycemia may inhibit pathological processes that are closely related and induced by hyperglycemia such as increased oxidative stress and glycation of cellular proteins and lipids (4). Therefore, it is crucial to achieve a gradual optimization of $\mathrm{HbA} 1 \mathrm{c}$ levels between $6.5 \%$ and $7 \%$, recommended level, as a long-term form of management in order to reduce the incidence of macro and micro-vascular complications in DM patients (5).

Laboratory tests for monitoring diabetes mellitus patients are plasma glucose (random sample), glucose in urine, glycated proteins, glycated hemoglobin (HbA1c), fructosamine, urinary proteins (microalbuminuria, proteinuria), C-peptide, insulin, parameters of lipid status and kidney function (6). Hemoglobin A1c represents the average glycemic value for the last 2-3 months in patients with diabetes. Based on the $\mathrm{HbA1c}$ value, an estimated mean glucose (eAG) value can be determined $(7,8)$.

Parameters obtained from hematologic counters can provide insight into changes that occur in hematological indices such as white blood cells (WBC), red blood cells (RBC), platelets (PLT), and the other parameters. Analysis of these parameters could contribute in the following-up of the development of degenerative complications in DM (9). White blood cells are well established biomarker of inflammation in cardiovascular disease as well as in T2DM and its complications. They could be activated by advanced glycation end products, angiotensin II, oxidative stress in T2DM, induced by hyperglycemia (10).

Recent studies have shown that the number of red blood cells is decreased, its lifespan is reduced in
Zaključak: Na osnovu dobijenih rezultata našeg istraživanja može se zaključiti da postoji povezanost između pojedinih hematoloških parametara i glikoregulacije kod pacijenata sa dijabetesom.

Ključne reči: DMT2, parametri KKS, trombociti, HbA1c

T2DM due to elevated blood glucose (11). In a large prospective study ETDRS, authors have found that decreased $\mathrm{Hb}$ and $\mathrm{HCT}$ levels are associated with increased risk of T2DM microangiopathy progression. Possible mechanisms combine reduced erithrocytes survival, hypoxemia and decreased erythropoiesis (12).

Activated platelets and leukocytes at the sites of damaged endothelium release vasoactive substances such as leucotrien, serotonin, thromboxane A2 that lead to vasospasm and favourably influence the development of thrombus (13). Additionally, platelets express numerous adhesion molecules and ligands that facilitate interactions among platelets, leukocytes, and endothelium, by direct modulation of the activity of leukocytes (neutrophils, lymphocytes) with phagocytosis and oxidative stress; and endothelium with adhesion molecule and chemokine expression (14).

The risk factors for T2DM are variable such as hyperglycemia, hypertension, hyperlipidemia and obesity, and fixed like: age, duration of diabetes and pregnancy. The results of the ADDITION study have shown that patients with retinopathy have significantly higher $\mathrm{HbA} 1 \mathrm{c}$ as well as systolic and diastolic blood pressure than patients without retinopathy (15).

Early Treatment Diabetic Retinopathy Study (ETDRS) data have shown that elevated serum lipid levels such as total cholesterol, low density lipoprotein cholesterol are associated with an increased risk for micro- and macro-vascular complications in diabetics (16). The low level of HDL cholesterol most commonly exists in patients with type 2 diabetes; and it is one of the risk factors for cardiovascular outcomes (17). Obesity is a major risk factor for the development of insulin resistance and type 2 diabetes mellitus (T2DM) (18).

The aim of the study is to determine possible changes in the parameters of the complete blood count depending on glycoregulation, as well as other risk factors in patients with Type 2 Diabetes mellitus.

\section{Materials and Methods}

The study was a randomized cross-sectional study aimed at determining the association of the CBC parameters and glycemic control, as well as other risk factors (hypertension, hyperlipidemia, obesity, duration of the disease) in T2DM patients. 
All the procedures in the study were conducted according to the rules of the Helsinki Declaration, approved by the Ethical Committee of the Health Care Center »Dr. Milorad-Mika Pavlović« in Indjija, Serbia. All patients signed an Informed Consent to participate voluntarily in the study. Patient data are protected and used only for the purpose of the research.

\section{Study Population}

The study included a total of 178 patients with type 2 diabetes (T2DM), of both gender, over the age of 40 years, sent from the Diabetes Counseling Center of Health Care Center "Dr Milorad Mika Pavlović", to the Department of Laboratory Diagnostics. The exclusion criteria from the study were endocrinological diseases affecting the metabolism of glucose and lipids, hematological diseases, systemic diseases, pregnancy, acute diseases, degenerative diseases of the nervous system and malignancy (19). The presence of associated diseases was monitored via an electronic patient card.

To notice the possible correlation between the $\mathrm{CBC}$ parameters and T2DM the subjects were divided into two groups based on the glycemic regulation, according to the obtained values for $\mathrm{HbA} 1 \mathrm{c}$. The first group consisted of subjects with $\mathrm{HbA} 1 \mathrm{c} \leq 7 \%$ (regulated), and the second group with $\mathrm{HbA} 1 \mathrm{c}>7 \%$ (unregulated).

\section{Questionnaire}

The data were collected on the basis of a specially designed questionnaire for this research, which included demographic data, age, gender, smoking status, duration of diabetes, presence of associated illnesses (hypertension, coronary artery disease, dyslipidemia, stroke). The questionnaire was filled in by patients in cooperation with the doctor.

\section{Anthropometric measurement}

Anthropometric measurements were performed, with the subjects being lightly dressed and barefooted. Body Height (BH) was measured using Martin's anthropometer with a precision of $0.1 \mathrm{~cm}$. Body Weight (BW) was measured using an electronic scale type Omron BF214, with the accuracy of $40 \mathrm{~kg}$ to $150 \mathrm{~kg} \pm 1 \%$ (20). Measurement of fat percentage in the body was carried out by using the bioelectric impedance method. Body Mass Index (BMI) was obtained using the formula: $\mathrm{BMI}=\mathrm{BW} / \mathrm{BH}^{2}$, which is automatically calculated by the scale with the previously entered body weight (BW-kg), body height (BH$\mathrm{m})$, age and gender.

\section{Blood pressure measurement}

Blood pressure measurement (BP) was performed three times after a ten-minute standstill with the Riva-Rocci sphygmomanometer in $\mathrm{mmHg}$ and the mean value was estimated. Blood pressure values, greater than or equal to $140 / 90 \mathrm{mmHg}$ were considered hypertension.

\section{Blood collection}

Blood samples were collected after a night time famine of 12-14h. Testing of samples was carried at the Department of Laboratory Diagnostics. The material used to determine $\mathrm{CBC}$ 5-part difference and $\mathrm{HbA} 1 \mathrm{c}$ was venous blood collected in vacuum tubes with an anticoagulant EDTA (Ethylene Diamine Tetracetic Acid). To determine glucose and lipid status parameters, vacuum tubes were used without anticoagulants, but with gel separator. Hematology method involves the determination of parameters of complete blood count on the hematologic analyzer Advia120 (Siemens-Germany), that uses flowcitometry and VSC technology (volumen, conductivity, light scatter) method (9).

Complete blood count determination included: white blood cells - leukocytes (WBC), neutrophils (neutro), lymphocytes (lympho), monocytes (mono), eosinophils (eos), basophils (baso). The number of red blood cells - erythrocytes (RBC), hemoglobin concentration (HGB), hematocrit (HCT), mean corpuscular volume (MCV), mean corpuscular hemoglobin content $(\mathrm{MCH})$, mean cell hemoglobin concentration $(\mathrm{MCHC})$ and red blood cell distribution width (RDW). Number of the platelets (PLT), mean platelet volume (MPV), platelet distribution width (PDW), plateletcrit (PCT), mean platelet component (MPC), platelet component distribution width (PCDW), mean platelet dry mass (MPM), platelet dry mass distribution width (PMDW).

The values of glucose were determined by enzymatic methods with glucoso oxidase (GODPAP). Total cholesterol (TC) was analyzed with enzymatic methods using commercially available reagents consisted of cholesterol oxidase, esterase and peroxidase. The end products of TC were measured by spectrophotometry.

The method for determination of triglycerides (TG) is based on enzymatic reaction with glicerol-3phosphate-oxidase (GPO). High density lipoproteincholesterol (HDL-C) values were determined by direct measurement using polymer-polyanion method, and the value of low density lipoprotein-cholesterol (LDLC) was determined by the Friedewald equation. Index of atherosclerosis (IA) was determined by formula. The HbA1c value was analyzed by the method of immuno-turbidimetric inhibition (TINIA) in hemolized full blood. The target value for good glycemic control was hemoglobin A1c $\leq 7 \%$ by ADA (7). 
Determination of the biochemical parameters and hemoglobin A1c was done on the biochemical analyzer Advia 1200 (Siemens-Germany). Standardization, calibration, application of control material and sample processing are in accordance with the manufacturer's instructions (9).

\section{Statistical analyses}

The following statistical methods were used in the data analysis. In descriptive statistics we used the mean (arithmetic mean) and measure of variability, standard deviation (SD) for normally distributed data and median or interquartile range (IQR) for data with skewed distribution. The confidence interval ( $\mathrm{Cl} 95 \%)$ was also examined. Normality of the parameters was examined using boxplots and Kolmogorov-Smirnov tests. Student T-test and binary logistic regression were performed for testing the statistical significance between two groups with normal distibution of data. Binary logistic regression was performed to analyse parameters associated with T2DM in regulated and unregulated group of patients ( $\mathrm{HbA} 1 \mathrm{c}<7, \mathrm{HbA} 1 \mathrm{c}>7)$. For data with skewed distribution Mann-Whitney Utest, the logaritmic scale (log10) and inverse distribution function (IDF) were used.

For association between parameters of glycemic control and $\mathrm{CBC}$ 5-part difference parameters, we used univariate linear regression.

To determine connection between regulation of T2DM and CBC-5-part difference, adjusting for confounders, multiple linear regression was applied, and three models have been developed:

Model 1 adjusted for age, gender,duration of diabetes, weight, BMI.

Model 2 adjusted for parameters of complete blood count used in this study.

Model 3 adjusted for parameters of the lipid status.

Table I Type 2 Diabetes mellitus patients' demographic data, smoking status, number of comorbidites comparing those with $\mathrm{HbA} 1 \mathrm{c} 7$ and $\mathrm{HbA} 1 \mathrm{c}>7$ in all patients.

\begin{tabular}{|c|c|c|c|c|c|}
\hline & \multicolumn{2}{|c|}{ HbA1c $\leq 7 \quad(n=94)$} & \multicolumn{2}{|c|}{$\mathrm{HbA1c}>7(n=84)$} & \multirow{2}{*}{$\begin{array}{c}\text { T-test } \\
\mathrm{p}\end{array}$} \\
\hline & Number & $\%$ & Number & $\%$ & \\
\hline Total & 94 & 52.82 & 84 & 49.19 & \\
\hline Male (M) & 32 & 48.48 & 34 & 51.52 & $>0.05$ \\
\hline Female (F) & 62 & 55.36 & 50 & 44.64 & $>0.05$ \\
\hline Smoking status & 34 & 52.31 & 31 & 47.69 & \\
\hline Disease0 & 33 & 56.9 & 25 & 43.1 & $>0.05$ \\
\hline Disease1 & 39 & 52 & 36 & 48 & $>0.05$ \\
\hline Disease2 & 22 & 48.89 & 23 & 51.11 & $>0.05$ \\
\hline
\end{tabular}


Table II Type 2 Diabetes mellitus patients' duration of disease, glycoregulation parameters, PMDW, HDL-C comparing those with $\mathrm{HbA} 1 \mathrm{c} \leq 7$ and $\mathrm{HbA} 1 \mathrm{c}>7$ in all patients.

\begin{tabular}{|c|c|c|c|c|c|c|c|c|}
\hline & \multicolumn{3}{|c|}{$\mathrm{HbA} 1 \mathrm{c} \leq 7(\mathrm{n}=94)$} & \multicolumn{3}{|c|}{$\mathrm{HbA} 1 \mathrm{c}>7(n=84)$} & \multirow{2}{*}{$\begin{array}{c}\text { T-test } \\
\mathrm{P}\end{array}$} & \multirow{2}{*}{$\begin{array}{c}\text { Bin. Log. } \\
\text { Reg. } \\
\text { P }\end{array}$} \\
\hline & $\begin{array}{l}\text { mean/ } \\
\text { median }\end{array}$ & $S D$ or IQR & $95 \% \mathrm{Cl}$ & $\begin{array}{l}\text { mean/ } \\
\text { median }\end{array}$ & SD or IQR & $95 \% \mathrm{Cl}$ & & \\
\hline DD & 7 & 4.311 & 0.0279 & 9 & 5.0333 & 0.0344 & 0.00115 & 0.003 \\
\hline GLUO & 8.1 & 1.421 & 0.0092 & 9.2 & 3.0665 & 0.021 & 0.0005 & 0.0005 \\
\hline GLU2 & 9.4 & 2.574 & 0.0166 & 11.5 & 3.9433 & 0.027 & 0.0005 & 0.0005 \\
\hline PMDW & 0.8 & 0.067 & 0.0004 & 0.81 & 0.0725 & 0.0005 & 0.04493 & 0.038 \\
\hline HDL-C & 1.2 & 0.351 & 0.0023 & 1.18 & 0.2698 & 0.0018 & 0.0067 & 0.011 \\
\hline
\end{tabular}

Legend: hba1c \%, Glycated hemoglobin in \%; DD, duration of the disease in year; GLU0, fasting glucose in mmol/L; GLU2, postprandial glucose in mmol/L; PMDW, Platelet Dry Mass Distribution Width in pg; HDL-C, high density lipoprotein-cholesterol in $\mathrm{mmol} / \mathrm{L}$

bin.log.reg. $p=0.011)$ (Table II). In total number of patients for univariate linear regression, $(n=178)$ it is shown that HCT was associated with DD $(p=0.001)$; MPC $(p=0.015)$, fasting glucose $(p=0.049), B W$ $(p=0.0005) ;$ PCT was associated with WBC $(p=0.0005)$, neutrophiles $(p=0.046)$, monocytes $(p=0.003) ; P M D W$ was associated with fasting glucose $(p=0.013)$, HbA1c $(p=0.049)$ HDL-C $(p=0.001), B W(p=0.043)$. In T2DM patients with HbA1C $\leq 7$ for univariate linear regression, $(n=94)$ it is shown that HCT was associated with fasting glucose $(p=0.003)$; PCT was associated with WBC $(p=0.0005)$, neutrophiles $(p=0.008)$, limphocytes $(p=0.014)$, monocytes $(p=0.033)$. In T2DM patients with $\mathrm{HbA} 1 \mathrm{C}>7$ for univariate linear regression, $(n=84)$ it is shown that HCT was associated with DD $(p=0.02), M P C(p=0.016), P D W(p=0.019), B W$ $(p=0.0005) ;$ PCT was associated with WBC $(p=$ $0.0005)$, monocytes $(p=0.0005), \operatorname{RBC}(p=0.027)$; PLT $(p=0.0005) ;$ MPM was associated with HDL-C $(p=0.002)$; PMDW was associated with HDL-C $(p=0.001)$. In multiple linear regresion for all patients, in model $1 \mathrm{HCT}$ was associated with duration of the disease (DD) of T2DM $(p=0.027)$, with body weight $(p=0.0005)$ and BMI $(p=0,045)$; PCT was associated with BMI $(p=0.027)$. In model 2 HCT was associated with MPV $(p=0.002)$ and MPC $(p=0.017) ; M P M$ was associated with PMDW $(p=0.0005)$. In model 3 HCT was associated with HDL-C $(p=0.001), M P M$ with HDL-C $(p=0.024)$ and PMDW with HDL-C $(p=0.031)$. In multiple linear regresion for regulated patients, in model $1 \mathrm{HCT}$ was associated with age $(p=0.037)$. In model 2 MPM was associated with PMDW ( $p=0.0005)$. In model 3 HCT was associated with HDL-C $(p=0.0005)$, PCT was associated with triglycerides $(p=0.008)$. In multiple linear regression for unregulated patients, in model 1 HCT was associated with BW $(p=0.001)$. In model 2 HCT was associated with MPV $(p=0.014)$, PCT was asssociated with WBC $(p=0.01)$, neutrophiles $(p=0.002)$, limphocytes $(p=0.003)$, monocytes $(p=0.006)$, eosinophiles $(p=0.036)$ and with MPC $(p=0.003) ;$ PMDW was associated with RBC $(p=0.005)$, with $\mathrm{MCH}(p=0.036)$ and with MPM $(p=0.0005)$. In model 3 HCT was associated with HDL-C ( $p=0.007)$; MPM with HDL-C $(p=0.019)$ and PMDW with HDL-C $(p=0.008)$. In multiple linear regression adjusted for all parameters, HCT was associated with MPV $(p=0.002), M P C(p=0.021)$; MPM was associated with HGB $(p=0.025) ;$ PMDW was associated with DD $(p=0.03)$ (Data are not shown in tables). For other parameters there were no statistical significances.

\section{Discussion}

Diabetes mellitus is one of the most common multisystemic diseases with microangiopathic and macroangiopathic complications. In T2DM hyperglycemia disturbs hematological indices and together with well recognised risk factors could lead to its degenerative complications. In our study there was no correlation between WBC and parameters of glycoregulation. However, other studies have shown association between WBC and impaired glucose control. Chronic inflammatory state in DM due to insulin action on the adipose tissue, muscles and liver promote differentiation and maturation of $W B C$ via proinflammatory cytokines (10).

In a study conducted by Irace $C$ et al. (12) hemoglobin, hematocrit and whole blood viscosity were significantly lower in subjects with retinopathy compared with subjects without microvascular complication, retinopathy. Possible mechanisms for decreased RBC indices in T2DM are structural modifications of erythrocytes membrane, changes of surface electric charge, erythrocyte aggregation, that 
could lead to the shorter lifespan of RBC. According to Malandrino $\mathrm{N}$ et al. (21). RDW was elevated in the patientes with macro and microvascular complications in diabetes. However, in Duman E et al. (22) study the correlation between RDW and peripheral arterial disease was not found.

There is a correlation between hematocrit (HCT) and duration of diabetes (DD), body weight (BW) in our study in the patients with $\mathrm{HbA} 1 \mathrm{c}>7$ group (unregulated diabetes group).

Insulin resistance is commonly present in T2DM and associated with a disorder of platelet function due to insulin action. The complete coagulation cascade is dysfunctional in T2DM (13).

Studies of Jindal et al. (23) and Kodiatte et al. (24) have shown that platelet indices, MPV, especially PDW, differ in DM patients with and without microvascular complications. An increase in MPV may point to a possible indicator ofthe development of atherosclerosis associated with DM and vascular complications $(23,24)$.

In the study Kilicli-Camur $\mathrm{N}$ et al. (25) authors suggest that MPV is higher in patients with an acute myocardial infarction (AMI) and is also associated with higher mortality following MI. These findings raise the hypothesis of the potential importance of MPV in the underlying pathophysiology of cardiovascular disease $(25,26)$.

However, in our study, there is no statistically significant difference in the values of MPV among the groups. The explanation for this difference is perhaps a better regulation of glycemia with less vascular micro and macroangiopathies in T2DM patients in our study and later diagnosis of disease and its complications in the other studies.

Our results show that in the $\mathrm{HbA} 1 \mathrm{c} \leq 7 \%$ group there is a correlation between fasting glucose and platelets. Additionaly PCT is associeted with WBC, neutrophiles, lymphocytes and monocytes. Similar results were also obtained in the Levent Demirtas study (10). However, the results of other studies have not shown the correlation between platelets and other platelet indices and the regulation of $\operatorname{T2DM}(27,28)$.

The results of our study have shown that there is a statistically significant difference in the values of PMDW between regulated and unregulated T2DM patients (Table II), as well as association of PCT with fasting glucose and PLT, PCT with postprandial glucose in unregulated group of diabetic patients. There is also a correlation of RDW and PMDW with HbA1c and fasting glucose when we adjusted the analyses for all examined confounders. We have found also a correlation between PCT and triglyceride in the group of regulated patients.

UKPD and KPDS50 studies indicated that the development of microvascular complications, espe- cially retinopathy was closely related to the level of fasting glucose, the presence of hyperglycemia for more than 6 years and elevated blood pressure. Findings indicate the need for good glycoregulation and blood pressure control in order to reduce microvascular complications, like retinopathy progression (29). It has also been observed that the values of fasting and postprandial glucose are statistically higher in the group with unregulated versus those with regulated DM, in all observed patients (Table II). Data obtained from the pan European research indicate that low HDL-cholesterol is common in people with diabetes (17). The whole group of patients who were divided according to $\mathrm{HbA} 1 \mathrm{c}$ values had significant differences in HDL-cholesterol: lower values in the $H b A 1 c>7$ group than those with $H b A 1 c \leq 7$ (Table II) (30). There is a connection between HDL cholesterol with fasting and postprandial glucose as well as $\mathrm{HbA} 1 \mathrm{c}$ in all patients. In the group of patiens with $\mathrm{HbA1c}>7 \mathrm{HDL}$-cholesterol is associated with platelet indices (MPW, MPC, PDW, MPM, PMDW).

Overweight and prevalence of obesity are rapidly increasing in many countries. The World Health Organization recognized that there is a "global obesity epidemic « with the increased prevalence of T2DM. Both diseases have a combined background in genetic factors, environments, society changes - modernization 0 which lead to excessive nutrition and sedentary lifestyle. These factors are important, but it is difficult to provide consistent evidence of their effects (18).

In our study, we found that BW is associated with HDL-C and hematocrit, in a group of subjects with unregulated T2DM.

In patients with unregulated glycemia the hematological parameters such as platelets, WBC, PCT, MPM, PMDW are increased but the HCT is decreased in our study.

The limitations of this study are: the study was conducted in a population in which there was increased number of patients with T2DM, metabolic syndrome and obesity. There are also other factors, confounders that influence the occurrence of T2DM which could not be examined in this study.

Based on our study results it may be concluded that some of the parameters of $C B C$ could be useful tool in following up T2DM and potential markers of its complications, such as platelets, WBC, PCT, MPM, PMDW, HCT. The relationship among other risk factors such as lipoproteins, anthropometric measurements and development of T2DM and its complications is well recognized, and studied in multiple studies. Our findings suggest that hematological indices are accessible, useful, simple, inexpensive laboratory parameters which could be utilised in health care centers. Therefore, general practitioners are the first line for diagnosis and follow-up of T2DM patients who use these indices in daily practice. 
In order to confirm the results of our study there is a need for the future, larger size study.

Acknowledgments. We want to thank for his cooperation our data miner and analyst MSc Zoran Vukusic. This work is based and supported with resources and facilites of Department of Laboratory Diagnostics, Health Care Center "Dr Milorad Mika Pavlović, Indjija, Serbia.

\section{References}

1. World Health Organization (WHO). Diabetes research. Available at: http: //www.who.int/diabetes/en/ (Last accessed on May 10, 2017)

2. Incidencija i mortalitet od dijabetesa u Srbiji 2016. Institut za javno zdravlje Srbije »Dr Milan Jovanovi Batut", 2016. Available at: http://www.batut.org.rs/ index.php?Content $=187$ (Last accessed on May 5, 2017)

3. Ziaee A, Ghorbani A,Kalbasi S, Hejrati A, Moradi S. Association of hematological indices with prediabetes: A cross-sectional study. Electronic Physician 2017; 9(9): 5206-11.

4. Drzewoski J, Kasznicki J, Trojanowski Z. The role of « in the natural history of diabetes mellitus. Pol Arch Med Wewn 2009; 119(7-8): 493-500.

5. Ting DS, Cheung GC, Wong TY. Diabetic retinopathy: global prevalence, major risk factors, screening practices and public health challenges: a review. Clin Exp Ophthalmol 2016; 44(4): 260-77.

6. Majkic-Singh N. Medicinska biohemija II. Društvo medicinskih biohemičara Srbije. Beograd; 2006.

7. American diabetes association (ADA). Available at: http: //www.ndei.org, http: //www.diabetes.org (Last accessed on June 15, 2017).

8. Kilpatrick ES, Rigby AS, Atkin SL. A1C variability and the risk of microvascular complications in type 1 diabetes: data from the Diabetes Control and Complications Trial. Diabetes Care 2008; 31(11): 2198-202.

9. Advia Systems. Available at: http: //www.healthcare. siemens.com/hematology/systems/advia-120-hematology-system (Last accessed: June 12, 2017).

10. Demirtas L, Degirmenci H, akbasem, Ozcicek A, Timuroglu A, Gurel A, Ozcicek F. Association of hematological indicies with diabetes, impaired glucose regulation and microvascular complications of diabetes. Int J Clin Exp Med 2015; 8(7): 11420-7.

11. Engstrom G, Smith J G, Persson M, Nilsson P M, et al. Red cell distribution width, haemoglobin A1c and incidence of diabetes mellitus. Journal of Internal Medicine 2014; 276: 174-83.

12. Irace $C$, Scarinci F, Scorcia $V$, Bruzzichessi D, Fiorentino $\mathrm{R}$, Randazzo G, et al. Association among low whole blood viscosity, haematocrit, haemoglobin and diabetic retinopathyin subjects with type 2 diabetes. $\mathrm{Br} J$ Ophthalmol 2011; 95(1): 94-8.
This research did not receive any specific grant from funding agencies in the public, commercial, or non-profit sectors.

\section{Conflict of interest statement}

The authors state that they have no conflicts of interest regarding the publication of this article.

13. Baklaja R, Elezovic I, Miljic P, Mikovic T, Lucic AM. Hemostaza, koagulacija krvi i fibrinoliza. In: Laboratorijska dijagnostika poremecaja hemostaze. Interlabexim, Beograd, 2008: 7-22.

14. Jenne CN, Urrutia R, Kubes P. Platelets: bridging hemostasis, inflammation, and immunity, Int J Lab Hematol 2013; 35(3): 254-61.

15. Bek T, Lund-Andersen $H$, Hansen $A B$, Johnsen $K B$, Sandbaek A, Lauritzen T. The prevalence of diabetic retinopathy in patients with screen - detected type 2 diabetes in Denmark: the ADDITION study. Acta Ophthalmol 2009; 87(3): 270-4.

16. Early Treatment Diabetic Retinopathy Study Research Group. Photocoagulation for diabeticmacular edema; ETDRS report no. 1. Arch Ophtalmol 1985; 103: 1796-806.

17. Puhalo-Sladoje D, Kisić B, Mirić D. The monitoring of protein markers of inflammation and serum lipid concentration in obese subjects with metabolic syndrome. J Med Biochem 2017; 36: 366-74.

18. Collinson P. Laboratory medicine is faced with the evolution of medical practice. J Med Biochem 2017; 36: 211-15.

19. Xu L, Zhou B, Li H, Liu J, Du J, Zang W, et al. Serum Levels of Progranulin Are Closely Associated with Microvascular Complication in Type 2 Diabetes. Dis Markers 2015; 357279.

20. Prizma, Operating instructions Omron BF 214, 2016. http: //www.prizma.rs/sr/index.php/omron/fitnes/bf214 (Last accessed: September 12, 2017)

21. Malandrino N, Wu WC, Taveira TH, Whitlatch HB, Smith RJ. Association between red blood cell distribution width and macrovascular and microvascular complications in diabetes. Diabetologia 2012; 55(1): 226-35.

22. Duman E, Kulaksızoglu S, Cifci E, Ozulku M. Is there a real correlation between red cell distribution width and peripheral arterial disease? J Med Biochem 2017; 36: 309-13.

23. Jindal S, Gupta S, Gupta R, Kakkar A, Singh HV, Gupta $\mathrm{K}$, Singh S. Platelet indices in diabetes mellitus: indicators of diabetic microvascular complications. Hematol 2011; 16(2): 86-9.

24. Kodiatte TA, Manikyam UK, Rao SB, Jagadish TM, Reddy M, Lingaiah HK, Lakshmaiah V. Mean platelet 
volume in Type 2 diabetes mellitus. J Lab Physicians 2012; 4(1): 5-9.

25. Kilicli-Camur N, Demirtunc R, Konuralp C, Eskiser A, Basaran $\mathrm{Y}$. Could mean platelet volume be a predictive marker for acute myocardial infarction? Med Sci Monit 2005; 11(8): 387-92.

26. Chu SG, Becker RC, Berger PB, Bhatt DL, Eikelboom JW, Konkle B, Mohler ER, Reilly MP, Berger JS. Mean platelet volume as a predictor of cardiovascular risk. A systematic review and meta-analysis. J Thromb Haemost 2010; 8(1): 148-56.

27. Ozder A, Eker HH. Investigation of mean platelet volume in patients with type 2 diabetes mellitus and in subjects with impaired fasting glucose: a cost-effective tool in primary health care? Int J Clin Exp Med 2014; 7(8): 2292-7.
28. Jabeen F, Fawwad A, Rizvi HA, Alvi F. Role of platelet indices, glycemic control and hs-CRP in pathogenesis of vascular complications in type- 2 diabetic patients. Pak J Med Sci 2013; 29(1): 152-6.

29. Kohner EM, Aldington SJ, Stratton IM, Manley SE, Holman RR, Matthews DR, Turner RC. United Kingdom Prospective Diabetes Study, 30: diabetic retinopathy at diagnosis of non-insulin-dependent diabetes mellitus and associated risk factors. Arch Ophthalmol 1998; 116(3): 297-303.

30. Rodriguez-Fontal M, Kerrison JB, Alfaro DV, Jablon EP. Metabolic control and diabeticretinopathy. Curr Diabetes $\operatorname{Rev} 2009$; 5(1): 3-7.

Received: April 4, 2018

Accepted: July 4, 2018 